\title{
BANGUNAN "SEMI VERTIKAL" DI KAWASAN DINDING BENTENG KRATON YOGYAKARTA. KAJIAN ASPEK VERNAKULAR DALAM PELESTARIAN SETING BANGUNAN DAN KAWASAN
}

\author{
Dina Poerwoningsih* \\ Jurusan Teknik Arsitektur, Fakultas Teknik Universitas Merdeka Malang \\ *dinatatatit@gmail.com
}

\begin{abstract}
ABSTRAK
Benteng Kraton Yogyakarta merupakan salah satu elemen pembentuk struktur kota tradisional Yogyakarta disamping Kraton, Tamansari, dan Dalem. Seperti halnya permasalahan kota-kota yang bernilai historis lainnya, isu-isu preservasi dan konservasi menjadi salah satu wacana dalam menyikapi pertumbuhan dan perkembangan kota. Secara visual dan fisik, saat ini Benteng Kraton Yogyakarta hanya tersisa kurang dari seperempat bagian saja. Selebihnya dan sebagian besar kini menjadi area hunian bagi sebuah komunitas masyarakat Yogyakarta. Kondisi benteng saat ini sangat memperlihatkan karakter kontemporer suatu lingkungan urban. Seperti halnya Tamansari yang telah mengalami perubahan fisik jauh lebih awal, Benteng Kraton dapat diprediksi akan mengalami hal yang sama. Lingkungan Kraton Yogyakarta dengan keberadaan monumen bersejarahan di dalamnya menuntut upaya pemeliharaan, di sisi lain kebutuhan masyarakat warga lingkungan Kraton menuntut pemenuhan yang tidak sejalan dengan upaya pemeliharaan tersebut. Salah satu upaya Kraton untuk melestarikan eksistensi Benteng Kraton sebagai bangunan bernilai sejarah adalah diaturnya ketinggian bangunan di kawasan Kraton yang tidak melebihi tinggi Bangunan Kraton. Kondisi yang ada saat ini menunjukkan adanya kecenderungan untuk mengabaikan aturan tersebut untuk alasan-alasan pemenuhan kebutuhan dalam kehidupan masyarakat kawasan. Diperlukan suatu pemahaman dan upaya-upaya kompromi yang dapat menghubungkannya. Upaya revitalisasi merupakan salah satu pendekatan yang dipandang paling optimal. Mendukung upaya revitalisasi tersebut, memahami bagaimana suatu komunitas hidup dalam suatu urban heritage menjadi sangat penting. Bangunan "Semi Vertikal" merupakan salah satu fenomena-vernakular yang dilakukan masyarakat dalam rangka mengapresiasi aturan Kraton. Tulisan ini ditujukan untuk memaparkan fenomena "istimewa" tersebut.
\end{abstract}

Keywords - Vernakular, Nilai Vernakular, Bangunan Semi Vertikal.

\section{PENDAHULUAN}

Vernakular dalam arsitektur dapat dipandang sebagai artifak di masa lalu, properti di masa sekarang, dan sumber potensi pengembangan di masa yang akan datang. Diperlukan pemahaman, pengetahuan, dan visi yang berpijak pada pandangan ke masa lalu dan masa depan, pada tradisi dan inovasi, pada aksi-aksi konservasi, utilisasi dan pengembangan. Hatmoko (1999).

Dalam memahami masa lalu dan masa depan tentu saja tidak harus mendasarkan pada tonggak batasan waktu yang sangat mengikat, sebagaimana proses kehidupan yang mengalir, proses vernakular bersifat timeless. Vernakular merujuk pada sifatnya yang dihasilkan oleh 
pengrajin/tukang ketimbang arsitek, sifat dibangunnya dengan menggunakan teknik lokal, material lokal, serta digagas untuk menyikapi lingkungan "lokal". Vernakularitas atau sifat vernakular sangat jauh dari karakter sophisticate atau fashionable. (Jackson, 1984)

Diperlukan suatu pemahaman dan upaya-upaya kompromi yang dapat menghubungkannya. Adalah penting untuk memahami bahwa melestarikan eksistensi Benteng Kraton sebagai bangunan bernilai sejarah mempertimbangkan konteks kebutuhan jaman ini.

"When we discuss the process and developtment of urban area, we deal with dynamic characters of the city. Maintaining the city identity using the architectural heritage means understanding the position of the heritage within the dynamic context of city developtment " (Kostof, 1992)

Mengingat nilai sejarah dan juga makna simbolik yang dimiliki Benteng Kraton Yogya, sudah seharusnya eksistensi tetap dipertahankan dalam rangka memperkuat identitas Kota Yogyakarta. Oleh karenanya memahami bagaimana suatu komunitas hidup dalam suatu urban heritage menjadi sangat penting. Melihat vernakularitas pada suatu entitas yang ada pada masa sekarang bisa saja dikaitkan dengan bagaimana entitas tersebut berinteraksi dengan kondisi lokal saat ini. Maksudnya adalah masyarakat pada saat ini (dalam modernitasnya) bisa saja menjadi latar belakang terciptanya produk vernakular pada masa sekarang, yang tentu saja berpotensi menjadi resource di dalam pengembangan di masa mendatang.
Dalam isu-isu konservasi, seperti halnya yang terjadi di KBDKY saat ini, sudah seharusnya masyarakat menjadi salah satu aktor yang terlibat dalam upayaupaya pengembangan di masa mendatang. Apabila upaya konservasi ditujukan untuk menunda perubahan, maka melihat bagaimana masyarakat KBDKY menyikapi seting historis lingkungan mereka bisa menjadi pilihan bijak.Berangkat dari beberapa tesis tersebut di atas, tulisan ini mencoba memaparkan beberapa fenomena vernakular pada bangunanbangunan rumah tinggal yang ada di Kawasan Dinding Benteng Kraton Yogyakarta (KDBKY).

Tulisan ini dimaksudkan untuk memperlihatkan beragam fungsi dan aktifitas penghunian rumah-rumah di KDBKY saat ini yang dilakukan seperti pada umumnya sebuah kampung kota. Keterbatasan lahan memiliki keterhubungan dengan adanya fenomena pemanfaatan jalan kampung dengan berbagai aktifitas. Dalam penelitian yang telah dilakukan (Poerwoningsih, 2007), secara khusus didapatkan pula stereotipe yang menarik dari penghuni dalam melakukan adaptasi dan adjusment dalam konteks Urban Heritage Environment di lingkungan Kraton. Dalam tulisan ini fenomena tersebut dieksplorasi karakter-karakternya sebagai produk yang bernilai vernakular.

\section{METODE PENELITIAN}

Penelitian ini dilakukan dengan metode kualitatif deskriptif. KDBKY dipandang sebagai kawasan permukiman yang unik. Eksistensinya dipengaruhi oleh keberadaan Kraton dalam konteks magersari. Unit 
penelitian adalah kawasan permukiman dan unit rumah tinggal. Kawasan permukiman terbagi menjadi 4 penggal kawasan di sisi utara, selatan, barat dan timur. Unit rumah ditentukan secara purposif di ke empat ruas jalan yang mengelilingi benteng yang berada di 4 penggal kawasan. Vernakularitas yang diteliti dikaitkan dengan 2 hal yaitu (1). persepsi dan motivasi penghuni terhadap huniannya dan (2). seting-seting fisik dan ruang hunian. Pengumpulan data persepsi dengan menggunakan kuesioner, sementara data seting fisk dan ruang hunian dengan menggunakan visual mapping.

\section{PEMBAHASAN}

\section{Sejarah Singkat Benteng Kraton Yogyakarta}

Keberadaan benteng kraton tidak lepas dari keberadaan Kraton Ngayogyakarta Hadiningrat sebagai inti Kota Yogyakarta. Mulai tahun 1756 dibangun berbagai macam sarana dan bangunan pendukung untuk mewadahi aktifitas pemerintahan, yang tidak hanya memenuhi aspek fungsi saja melainkan aspek politis, strategis, teknis, dan filosofis religius.

Dari aspek strategis, pembangunan kraton mempertimbangkan secara matang strategi pertahanan keamanan, politik, dan sosial budaya. Cepuri Kedhaton merupakan ring (lingkaran) pertahanan utama, Baluwarti (Benteng) berikut jagang (parit keliling benteng) merupakan ring pertahanan pertama, sungai Code dan sungai Winongo merupakan ring pertahanan kedua, Sungai Gajah Wong dan Sungai Bedhog merupakan ring pertahanan ketiga, serta Sungai Opak dan Sungai Progo merupakan ring pertahanan keempat. Apabila dikaitkan dengan upaya preservasi urban heritage elemen-elemen yang berperan dalam ring-ring pertahanan menjadi suatu jalinan yang erat dalam memperkuat identitas kota. ${ }^{1}$

Secara fisik, benteng dibangun mulanya berupa dinding setebal 3 meter dan tinggi 3 meter. Di bagian atas digunakan untuk area pengawasan sekaligus semacam lintasan yang dapat dilewati kereta. Dibangun dengan struktur bentuk geometris persegi empat pada prinsipnya, dengan beberapa elemen bangunan sebagai penanda pada tempat-tempat tertentu antara lain berupa gerbang (plengkung dan regol), dan ujung sudut benteng (pojok beteng). Kini sebagian elemen telah hancur sebagian besar karena bencana alam dan peperangan, sebagian lainnya karena unsur pengrusakan masyarakat setempat.
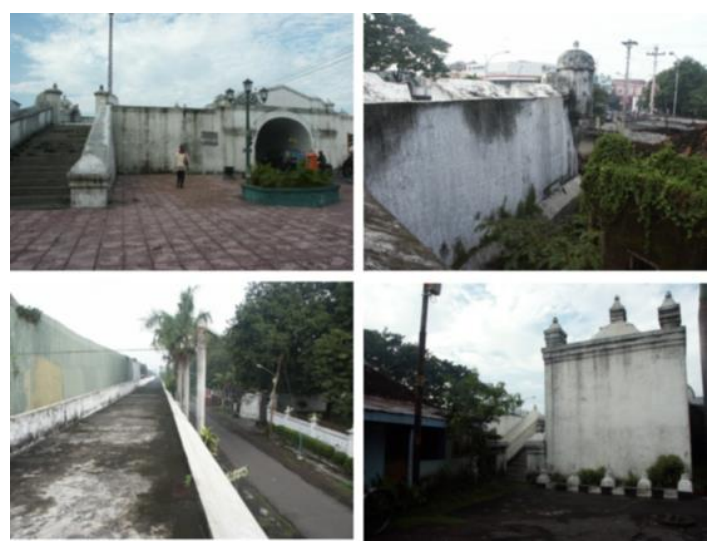

Gambar 1. Situs Benteng yang masih tersisa (Dokumentasi 2007)

${ }^{1}$ Lampiran Perda Kota Yogyakarta No. 6 Tahun 2004 
Hilang atau hancurnya sebagian besar bangunan benteng, ditunjang kondisi perkembangan Kraton Yogyakarta, menyebabkan area bekas benteng yang hancur tersebut menjadi sebuah areal terbuka yang tidak terurus dan tidak terpakai. Kondisi tersebut disikapi pihak Kraton pada periode Sri Sultan Hamengku Buwono IX dengan memperbolehkan warga masyarakat setempat yang tidak memiliki rumah untuk membangun rumah di atas areal tersebut sejak tahun1969. Ijin diberikan dengan beberapa ketentuan dan persyaratan.

Proses regenerasi dari para pemukim, ditunjang alasan ekonomi, serta lemahnya penegakan atas aturan kesepakatan oleh pihak kraton sendiri telah menyebabkan perkembangan bangunan-bangunan menjadi cenderung tidak terkontrol. Secara fisik maupun spasial benteng menjadi sebuah seting yang sama sekali berbeda dengan pada mulanya.

\section{Eksistensi KDBKY}

Bagaimana kondisi KDBKY saat ini sangat perlu untuk dipaparkan sebagai konteks yang melatarbelakangi bagaimana masyarakat penghuni kawasan tersebut mempersepsikan lingkungannya. Pada mulanya, Kraton Yogyakarta dikelilingi bangunan benteng setebal kurang lebih $3 \mathrm{~m}$. Kini yang masih tersisa adalah yang berada di sisi selatan timur saja. Atas kebijaksanaan penguasa kraton (Sri Sultan Hamengku Buwono IX), area bekas benteng tersebut diperbolehkan untuk dibangun rumah-rumah bagi warga pribumi yang tidak memiliki rumah. Warga pribumi tersebut sebelumnya tinggal di dalam wilayah "jeron beteng” ( wilayah dalam benteng). Mula-mula yang diperkenankan untuk dibangun adalah wilayah barat, utara, dan selatan, kemudian menyusul sisi sebelah timur, sesuai ijin kraton pada tahun 1969. Menurut informasi penduduk setempat, kebijaksanaan tersebut diturunkan atas dasar kekawatiran akan masuknya warga bukan pribumi yang berpotensi semakin merusak dinding benteng yang masih tersisa.

Atas perkenan tersebut, kini tak kurang dari 300 rumah/KK menempati area bekas benteng tersebut. Ijin ini diberikan kepada pemukim dengan beberapa syarat yang tertulis dalam suatu surat perjanjian antara pemukim dan pihak kraton. Persyaratan tersebut antara lain meliputi : rumah tidak boleh dikembangkan secara vertikal walaupun lahan terbatas, bangunan dibagi secara adil oleh pihak yang ditunjuk kraton dengan ukuran $3 \times 4 \quad \mathrm{~m} 2$, bangunan berbentuk kotangan/monyetan (dengan tinggi tembok tidak lebih dari $1 \mathrm{~m}$ dari muka tanah). Status kepemilikan rumah adalah magersari. Apabila sewaktu-waktu tanah diinginkan kembali oleh kraton, maka bangunan tersebut hanya diganti rugi sebesar $1 / 3$ dari harga bangunan ( Bappeda DIY, 1982). Sejak ijin dikeluarkan oleh kraton tahun 1969 tersebut, mulailah pembangunan rumah-rumah di bekas benteng kraton Yogyakarta. 

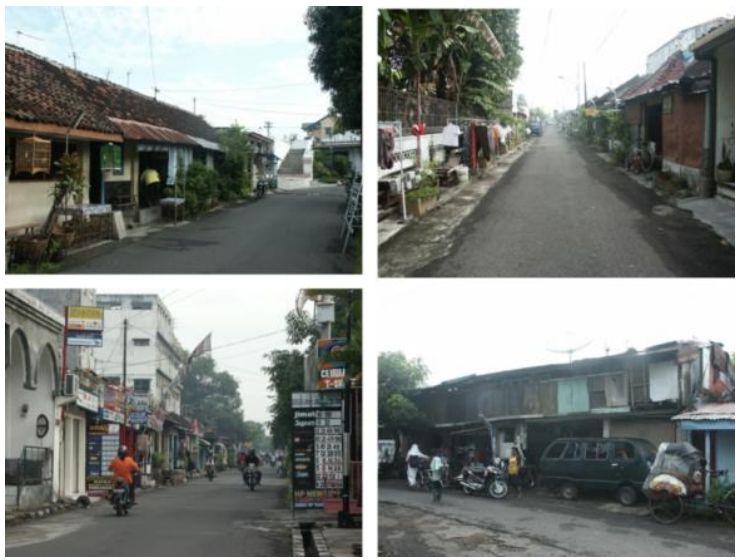

Gambar 2. Lansekap Lingkungan Kota Kontemporer di Kawasan Bekas Dinding Kraton Yogyakarta.

(Dokumentasi 2007)

\section{Persepsi Masyarakat Penghuni terhadap Peraturan Kraton}

Untuk mengetahui nilai atau motivasi yang melatarbelakangi perilaku membangun dari penghuni perlu diketahui bagaimana masyarakat penghuni tersebut mempersepsikan lingkungannya. Salah satunya adalah persepsi mereka terhadap Peraturan kraton.

Terkait dengan keberadaan permukiman di area bekas benteng dengan status magersari tersebut, sebagian besar masyarakat penghuni menyatakan telah mengetahui adanya aturan yang membatasi dalam proses menghuni maupun membangun. Data yang menunjukkan bahwa sebagian besar masyarakat telah mengetahui adanya peraturan yang disepakati pada awalnya oleh pihak Kraton dan warga, ternyata dalam realitanya berbeda dalam hal berperilaku membangunnya.

Tabel 1. Persepsi penghuni Bangunan di BDBKY (sumber : Poerwoningsih, 2007)

\begin{tabular}{l|l|l}
\hline $\begin{array}{l}\text { Persepsi Penghuni terhadap } \\
\text { Peraturan Kraton }\end{array}$ & \multicolumn{2}{|c}{$\begin{array}{l}\text { Number of } \\
\text { Responden }\end{array}$} \\
\hline $\begin{array}{l}\text { Mengetahui Adanya aturan dan } \\
\text { kesepakatan dari Kraton }\end{array}$ & 73 & $71 \%$ \\
\hline Mengetahui Status magersari & 90 & $87 \%$ \\
\hline $\begin{array}{l}\text { Mengetahui Aturan luasan } \\
\text { bangunan }\end{array}$ & 62 & $60 \%$ \\
\hline $\begin{array}{l}\text { Mengetahui Larangan pembangunan } \\
\text { secara vertikal/tingkat }\end{array}$ & 96 & $93 \%$ \\
\hline $\begin{array}{l}\text { Mengetahui Aturan dinding } \\
\text { kotangan/semi permanen }\end{array}$ & 62 & $60 \%$
\end{tabular}

Seluruh responden menyatakan telah merenovasi bangunan minimal 1-2 kali. Sebagian besar bangunan kini bahkan merupakan bangunan permanen

\section{Upaya Penghuni Menyikapi Keterbatasan Seting Lingkungan}

Pada dasarnya sebagian besar penghuni bangunan di KBDKY melakukan kegiatan membangun dan merubah bangunan tempat tinggalnya semata untuk memenuhi kehutuhan ruang. Meskipun demikian hasil penelitian yang lain memperlihatkan beberapa stereotipe perilaku menghuni yang bersifat positif, dalam cara-cara yang strategis dan kompromis. Perilaku tersebut (Poerwoningsih, 2007) sangat penting untuk dikaji dalam rangka menggali aspek-aspek spasial secara 
teknis yang bisa disumbangkan untuk kepentingan masa depan lingkungan permukiman ini. Temuan yang dihasilkan adalah :

\section{Seting beberapa aktifitas yang saling menggantikan (Substitutional Setting)}

Seting merupakan seting dari beberapa aktifitas ini terjadi di tempat yang sama namun dalam waktu yang berbeda. Aktifitas-aktifitas dapat terjadi dengan atau tanpa merubah seting fisik ruangnnya. Perilaku spasial seperti ini dapat ditunjukkan pada kasus ujung jalan Madyosuro yang digunakan untuk berjualan dengan jenis dagangan yang berbeda pada pagi (pedagang bubur), siang hari ( pedagang bakso), serta sore hingga malam hari (pedagang bakmi \& ronde).

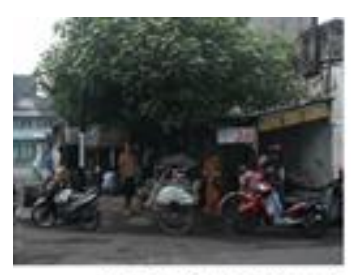

Seting Usaha Informal

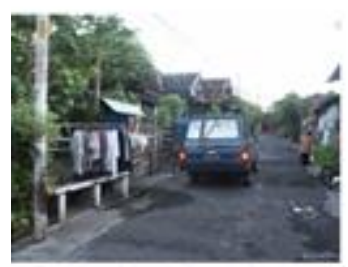

Seting keg. Rumah. tangga

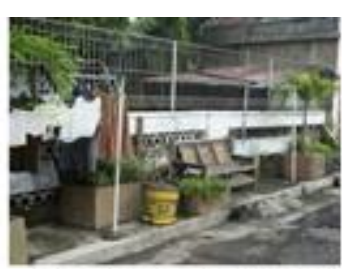

Seting interaksi tidak formal

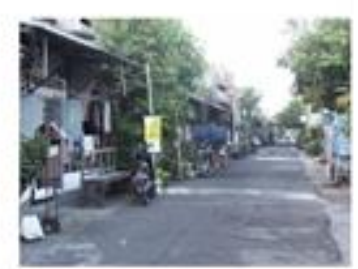

Seting persiapan usaha
Gambar 3. Kasus Substitutional Setting

(sumber : Dokumentasi 2007)
Kasus lain adalah seting kegiatan domestik/rumah tangga berupa areal jemur bersama pada pagi hingga siang hari, yang digunakan untuk aktivitas interaksi sosial (jagongan) pada sore hingga malam harinya.

\section{Ruang dan Fasilitas Komunal/bersama}

Keterbatasan daya dukung lingkungan serta keterbatasan pemukim secara individual pada lingkungan ini, mendorong untuk terciptanya ruangruang yang dapat digunakan secara bersama baik secara formal, maupun secara tidak formal. Fasilitas tersebut ditemukan pada kasus fasilitas MCK yang menunjang kegiatan domestik, fasilitas balai RW untuk kegiatan sosial kemasyarakatan secara formal, serta sekedar ruang terbuka di sisi jalan untuk berinteraksi sosial antar tetangga.

\section{Potensi Vernakularitas pada Bangunan Rumah Tinggal di Kawasan Dinding Benteng Kraton Yogyakarta.}

Keterbatasan lahan bangunan dan peraturan Kraton memiliki keterkaitan erat dengan fenomena perilaku masyarakat untuk membangun rumah tinggalnya secara vertikal. Beberapa rumah menunjukkan kecenderungan untuk melanggar aturan Kraton dengan membangun secara vertikal hingga bangunan benar-benar menunjukkan secara fisik bangunan 2 lantai, hingga tinggi bangunan melebihi tinggi 7 meter.

Sementara, fenomena perilaku membangun yang lain lebih "bijak" dengan cara menciptakan sebuah ruang optimal yang terletak tepat di bawah atap rumah. Ruang-ruang tersebut dilakukan untuk menambah 
ruang karena kebutuhan akan ruang. Dengan demikian menurut pandangan penghuni cara tersebut tidak melanggar aturan Kraton. Lantai atas ruang atap menggunakan material kayu yang bersifat tidak permanen. Ruang tersebut cenderung tidak nyaman mengingat iklim tropis menyebabkan ruang menjadi panas. Upaya mengatasi panas dilakukan dengan membuat jendela atau bukaan dinding atau atap.
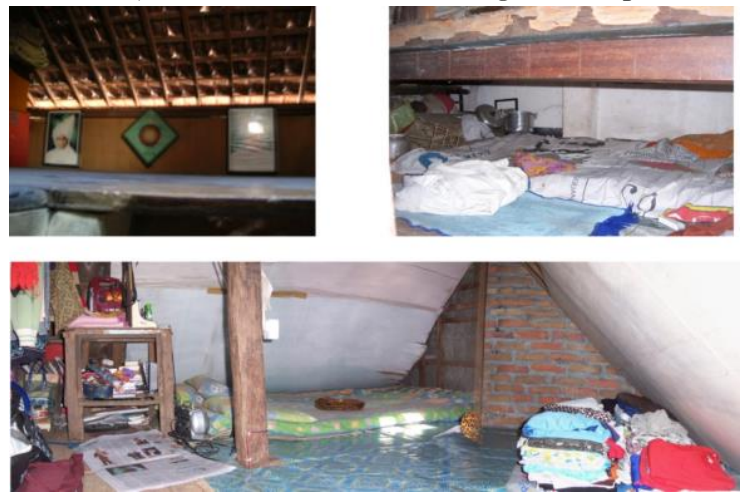

Gambar 4. Ruang Bawah Atap

(sumber: dokumentasi 2007)

Perilaku unik yang lain adalah mebangun bangunan secara vertikal dengan tinggi dinding "tidak penuh/semi vertikal. Dalam tulisan ini diistilahkan dengan "Bangunan Semi Vertikal". Pada dinding bangunan lantai atas tetap diletakkan jendela dan bukaan untuk ventilasi dan pencahayaan seperti terlihat pada gambar 5. Lantai ruang atas menggunakan bahan kayu maupun beton.

Performansi bangunan semi vertikal pada beberapa kasus menyerupai bangunan kolonial 1 lantai yang berdinding tinggi dengan ventilasi di bagian atas dinding, sementara pada bangunan di KBDKY adalah sebuah ruang di lantai kedua.
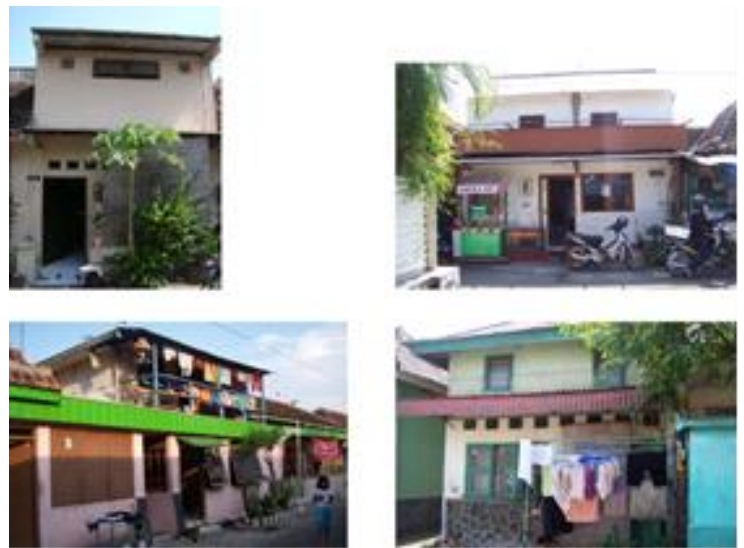

Gambar 5. Fasad Bangunan Semi Vertikal (sumber: dokumentasi 2007)

Performansi bangunan semi vertikal pada beberapa kasus menyerupai bangunan kolonial 1 lantai yang berdinding tinggi dengan ventilasi di bagian atas dinding, sementara pada bangunan di KBDKY adalah sebuah ruang di lantai kedua. Ruang-ruang tersebut biasanya digunakan untuk kegiatan privat misalnya, untuk ruang tidur, ruang sholat atau bahkan untuk gudang saja.Permasalahan bangunan yang dirasakan penghuni adalah pada berkurangnya kenyamanan akibat tidak optimalnya ukuran tinggi ruang lantai kedua. Observasi awal di beberapa bangunan menunjukkan beberapa upaya untuk mengatasinya misalnya dengan memaksimalkan bukaan untuk penghawaan atau pencahayaan. (lihat gambar 6) 

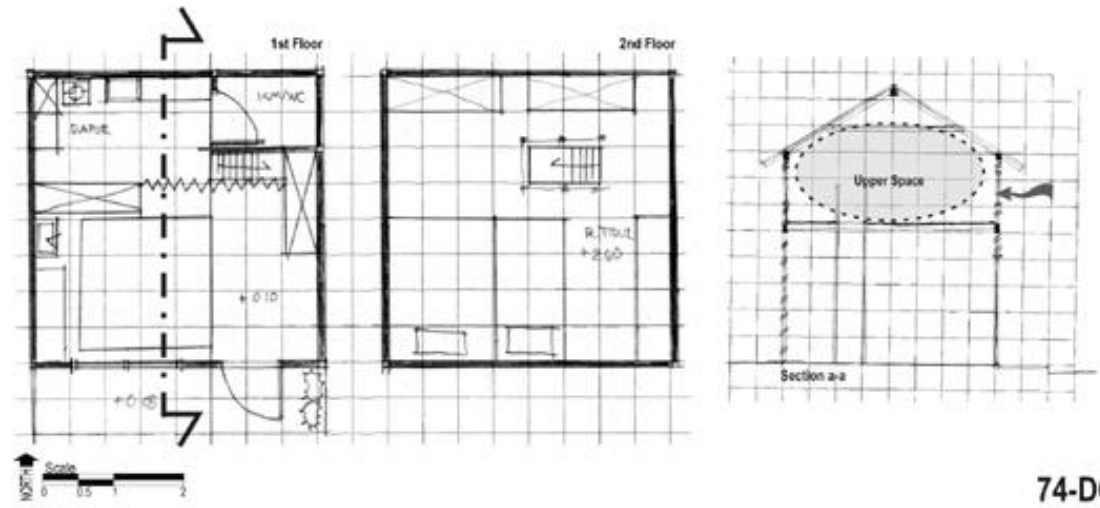

74-D6
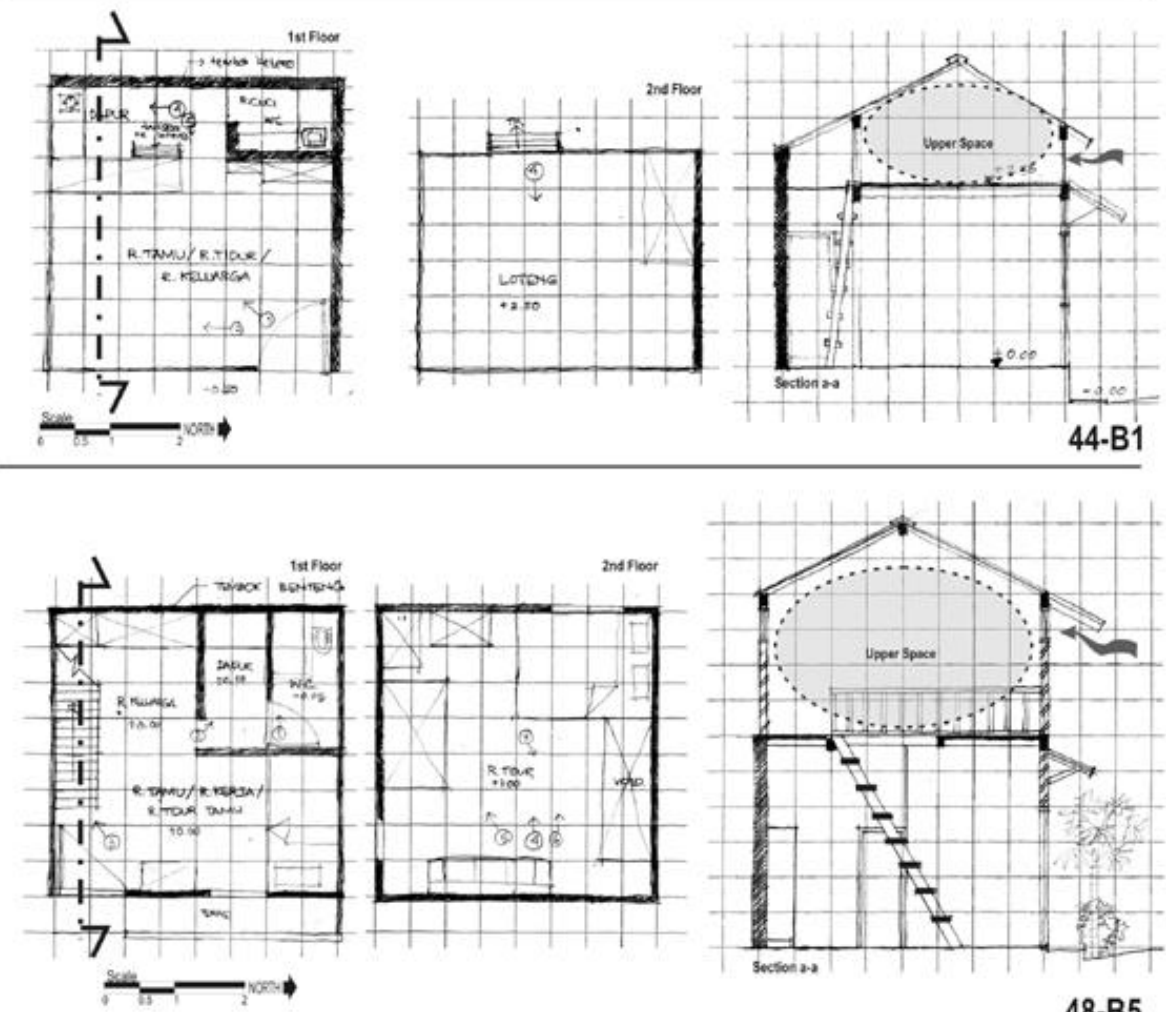

48-B5

Gambar 6. Denah dan Potongan Bangunan Semi Vertikal (sumber : Poerwoningsih, 2007) 
Fenomena Bangunan Semi Vertikal tersebut merepresentasikan beberapa hal sebagai berikut :

a. Adanya kemauan dan motivasi dari masyarakat penghuni untuk tidak mengabaikan begitu saja peraturan Kraton semata hanya untuk memenuhi kepentingan kebutuhan ruang. Fenomena bangunan semi vertikal sebenarnya adalah fenomena kultur dan juga sosial.

b. Penyelesaian bangunan oleh masyarakat penghuni memiliki keterbatasan dalam hal pengetahuan tektonika bangunan dan teknologi yang digunakan. Keterbatasan tersebut muncul dalam performansi kenyamanan bangunan yang masih belum optimal.

c. Peraturan kraton terutama dalam hal larangan untuk membangun bangunan melebihi 7 meter bangunan Kraton masih merupakan aturan yang "ditaati" oleh sebagian masyarakat penghuni. Peluang pengendalian bangunan dengan aturan tersebut masih terbuka.

\section{KESIMPULAN}

Terdapat beberapa aspek vernakular atau vernakularitas pada proses atau perilaku membangun dari masyarakat setempat dalam rangka menyikapi atau menghargai nilai-nilai historis dari kawasan yang ditinggalinya.

Dengan terus meningkat tantangan pengembangan, Lingkungan Kraton dihadapkan pada situasi kritis. Lingkungan istana berada dengan tepat dalam domain yang secara balance mengakomodir pendekatan pelestarian dan juga mengakomodir kebutuhan masyarakat karena perubahan jaman ke arah modern.

Suatu pemahaman mata rantai fenomena kultur sosial dan Kraton sangat diperlukan. Adalah penting untuk memahami untuk memelihara Benteng Kraton sebagai bangunan monumental dengan juga mempertimbangkan kebutuhan masyarakat pada jaman ini.

Nilai vernakular dalam Bangunan Semi Vertikal menawarkan beberapa pemecahan desain bagi pengembangan atau pranata pembangunan hunian di KBDKY.

\section{REFERENSI}

Hatmoko, Adi Utomo. (1999) Reinterpreting The Vernaculars. Proseding Seminar on Vernacular Settlement. Universitas Indonesia.

Jackson, John Brinckerhoff. (1984) Discovering the Vernacular Landscape. New Haven. Yale, University press.

Kostof, Spiro. (1992) The City Assembled. The Elements of Urban Form Through History. London. Thames and Hudson.

Moore, G. (1979) Environment-Behaviour Studies dalam Introduction to Architecture. Mc Graw Hill.

Poerwoningsih, Dina et all. (2007) Adaptasi Spasial Rumah di Bekas Benteng Kraton Yogyakarta. Hibah Penelitian A2 Jurusan Teknik Arsitektur Fakultas Teknik Universitas Merdeka Malang. 
Rapoport, A. (1969) House, Form, and Culture, Prentice Hall. Inc. Englewood Cliffs , N.J.

Rapoport, A. (1977) Human Aspect of Urban Form, toward a Man - Environment Approach to Urban Form and Design. Pergamon Press.

Rapoport, A. (1982) The Meaning of The Built Environment, A Non Verbal Communication Approach. Sage Publications.

Ronald, A. (1993) Transformasi Nilai-nilai Mistis dan Simbolis dalam Ekspresi Arsitektur Rumah Tradisional Jawa. Makalah Seminar Lembaga Javanologi. Yayasan Ilmu Pengetahuan Panunggalan.

Zeisel, J., (1981) Inquiry By Design : Tools For Environment - Behaviour Research. Cambridge University Press, Cambridge. 